\title{
IMPLEMENTATION OF GOVERNMENT FINANCIAL INFORMATION SYSTEMS TOWARD LOCAL GOVERNMENT FINANCIAL STATEMENTS: CASE STUDY IN DELI SERDANG, INDONESIA
}

\author{
Fitri Yani Panggabean* ORCID ID: 0000-0002-0589-1223 \\ Universitas Pembangunan Panca Budi, Gatot Subroto street, Medan, Indonesia \\ *fitriyani@dosen.pancabudi.ac.id
}

Received: 04. 22. 2021

Accepted: 05. 19. 2021

\begin{abstract}
This paper aims to determine how the application of government financial accounting systems for financial statements government in the Deli Serdang district. The autonomy that has been carried out since 1999 in Indonesia refers to Law number 32 of 2004, which has been revised. Thus, local governments are given the authority to manage finances independently. The use of finance must be carried out accountably and transparently. The study was conducted in the Deli Serdang regency government Indonesia, with descriptive qualitative research. The data were obtained primarily by the documentation technique, which is a regional financial statement document for two years, a central and local government regulation document. The results showed that; 1) preparation of financial statements, the Deli Serdang regency government has implemented a financial accounting system with inadequate equipment such as an uncomputerized system that has delayed financial statements; 2) delays in financial statements are also caused by unskilled human resources and a bit number of employees for the application of government financial accounting systems; 3) financial statements at the end of the year found that the calculation of the budget, calculation of the budget memorandum, cash flow, and balance sheets are in accordance. However, it is constrained by the unavailability of data comparisons with the previous year; and 4) the structure of government financial management organizations in the form of a direct line, in which leaders and employees have direct responsibility regarding their duties. This can facilitate the coordination of supervisors for the better.
\end{abstract}

Keywords: Government financial information systems, accounting systems, financial statements.

Rezumat. Lucrarea își propune să stabilească modul în care aplicarea sistemelor de contabilitate financiară guvernamentale pentru situații financiare este guvernată în districtul Deli Serdang. Autonomia care se desfășoară din 1999 în Indonezia se referă la Legea nr. 32 din 2004, care a fost revizuită. Astfel, guvernelor locale li se acordă autoritatea de a-și gestiona finanțele în mod independent. Utilizarea finanțelor trebuie realizată în mod responsabil și transparent. Studiul a fost realizat în guvernul de regență Deli Serdang Indonezia, cu cercetări calitative descriptive. Datele au fost obținute în principal prin 
tehnica de documentare, un document de reglementare a guvernului central și local de situație financiară regională timp de doi ani. Rezultatele au arătat: 1) pregătirea situațiilor financiare - guvernul de regență Deli Serdang a implementat un sistem de contabilitate financiară cu echipamente inadecvate, cum ar fi un sistem necomputerizat care a întârziat situațiile financiare; 2) întârzierile în situațiile financiare sunt cauzate și de resurse umane necalificate și de un număr mic de angajați pentru aplicarea sistemelor de contabilitate financiară guvernamentale; 3) situațiile financiare de la sfârșitul anului au constatat că calculul bugetului, calculul memorandumului bugetar, fluxul de numerar și bilanțurile sunt conforme. Cu toate acestea, este constrâns de indisponibilitatea comparațiilor de date cu anul precedent; și 4) structura organizațiilor guvernamentale de management financiar sub forma unei linii directe, în care liderii și angajații au responsabilitatea directă cu privire la atribuțiile lor. Acest lucru poate facilita coordonarea supravegherilor în bine.

Cuvinte cheie: Sisteme de informații financiare guvernamentale, sisteme contabile, situații financiare.

\section{Introduction}

Autonomy has been rolled out in Indonesia since 1999 with the enactment of Law Number 22 of 1999 [2] and then revised with Law number 32 of 2004 [1]. With this autonomy, local government are given the authority to manage their finances. This finance must, of course, be carried out accountably and transparently. The basic consideration is the conditions in the country and abroad. Domestic conditions indicate that people want openness and independence (decentralization).

With Law number 32 of 2004 [1] concerning local government and Law number 33 of 2004 [3] concerning fiscal balance between the central and local governments, there is a substantial change in regional management. This is due to local financial management is a tool to manage and regulate the needs of local governments to provide services to the community. Decentralization in accordance with Law number 22 of 1999 [2] concerning regional government and Law number 25 of 1999 [4] concerning central and local fiscal balance was implemented in 2001.

Efficiency and effectiveness in organizing governance need to be improved by paying attention to aspects of the relationship between the composition of the local government, the potential and diversity of the region, opportunities and challenges of global competition, by giving the widest possible authority to local governments accompanied by granting the rights and responsibility of carrying out autonomy in unity government administration system. The implementation of the principle of good governance in the reform period requires a paradigm shift in thinking and acting for all elements of the bureaucracy of the central and local governments.

Minister of Home Affairs Regulation number 29 of 2002 [5], implies that for the effectiveness objectives for managing the funds under its management, regional governments are required to prepare regional financial reports as part of the accountability reports of the heads of local governments. Therefore, the Deli Serdang regency government, which is a district in North Sumatra, is required to prepare a government financial accountability statement that includes the regional balance sheet, the budget of regional income and expenditure (Anggaran Pendapatan dan Belanja Daerah/APBD) statements, APBD memorandum, and cash flow statement. 
For the sake of compiling good financial statements, certainly not an easy job, it requires quality human resources and equipment used to support the application of the regional financial accounting system in preparing regional financial statements. Human resources are the financial managers of government administrators. Implementation of the government financial accounting system requires a thorough understanding of the implementation of government financial management and the continual improvement of the authorized institutions so that the creation of performance accountability of local government agencies as part of good governance can become a reality.

Government Regulation number 8 of 2006 clause 11 [6], concerning government financial accounting systems and reporting deadlines, that;

1) The regional financial management official compiles the financial statements of the local government to be submitted to the Governor/Regent/Mayor to fulfill the accountability of the APBD implementation.

2) The financial reports of the local governments as referred to in paragraph (1) shall be prepared based on the financial statements of the Regional Work Unit (Satuan Perangkat Kerja Daerah/SKPD) and the accountability report on the management of the regional treasury.

3) The financial reports referred to in paragraph (1) shall be submitted by the Governor/Regent/Mayor to the Audit Board of the Republic Indonesia (Badan Pemeriksa Keuangan/BPK) no later than 3 (three) months after the end of the fiscal year.

Based on the above, the authors would like to know what caused the delay in the implementation of the government financial accounting systems, so that the local government experienced a delay in reporting it. Based on the description above, the focus of the study aims to trace the application of the government financial accounting systems in the preparation of financial reports in the Deli Serdang regency government.

\section{Government Financial Accounting Systems}

The government accounting system at the central government level is regulated by financial minister regulations, while at the local government level governor/regent/mayor govern the regional regulations regarding regional financial management and are guided by government regulations regarding Government Accounting Systems. According to Panggabean and Dame [7], regional financial accounting is the accounting used by local governments to manage and manage regional finances. Local government financial accounting is part of the discipline of accounting that has its characteristics different from commercial accounting, namely (1) not aimed at measuring profits; (2) no owner's interests; (3) the existence of budget accounting.

The development of a government accounting system requires a relatively long time. Moreover, the development of this system began together with the reform of local financial management, in terms of planning and budgeting, treasury and accounting, including local cash management. Therefore the development of the system is very closely related to changes in these factors. All of these things can be run simultaneously.

The information generated from the accounting information system process is contained in the financial statements consisting of 1) budget realization, 2) balance sheet, 3) cash flow and 4) notes to financial statements. In addition to the four elements of the financial statement elements stated above, each region is required to submit information 
relating to local finance, namely the financial statements of the Regional Owned Enterprises and data relating to the needs and economic potential of the region.

Accounting information data reported is associated with non-financial data such as statistical data that allows government agencies to assess efficiency, to the extent that resources have been used economically and an assessment of the effectiveness of an agency can provide optimum services with available resources, including assessing whether the results of a program can achieve the intended consequences. For example, programs launched to tackle poverty, eradicate infectious diseases, eradicate crime or reduce school drop-out programs, have been successful by their objectives.

Based on the description above, explicitly explain the context of using accounting information data to evaluate the extent to which public policies are implemented by program managers and adhere to the achievement of goals within the specified funding limits. By comparing budget terms with realization, it can be determined how much is spent and in certain areas and spending patterns, where differences have been anticipated previously.

\section{The Policy of Government Financial Accounting System Development}

Based on Government Regulation number 105 of 2000 [8], the local government must determine the accounting system used in the form of regional regulations. The development of the accounting system must be guided by the principles of developing the accounting system stipulated by the Minister of Home Affairs Regulation number 29 of 2002 [5]. The regulation only regulates the main matters, in connection with that the local government by the authority obtained by Government Regulation number 105 years 2000 [8], must develop an accounting system that can produce regional financial statements by these guidelines that take into account the situation and conditions of each region. In the Decree of the Minister of Home Affairs number 29 of 2002 [5] also stated that the accounting system was prepared by Government Financial Accounting Standards. Therefore, if there are discrepancies, among other things, the items regulated in the Decree of the Minister of Home Affairs and Local Government Accounting Standards should refer to Government Financial Accounting Standards.

\section{Regional Financial Report}

According to Government Regulation number 71 of 2010 [9] concerning Government Accounting Standards, financial statements are prepared to provide relevant information concerning the financial position and all transactions carried out by a recording entity during one reporting period. The term "Local Government Financial Statements" includes all reports and several explanations that acknowledge the report will be recognized as part of the financial statements.

According to Kasmir [10], the purpose of making financial statements is to provide information about; (1) type and amount of assets owned by the company at the present; (2) type and amount of liabilities and capital owned by the company at the present; (3) the type and amount of income earned in a certain period; (4) the amount and type of costs incurred by the company in a certain period; (5) changes that occur in assets, liabilities, and capital; (6) company management performance in a period; (7) notes to the financial statements; and (8) other financial information.

Local financial statements are structured representations of the financial position of transactions carried out by a local government entity. The general objective is to have a 
predictive and prospective role, to provide information that is useful for predicting the number of resources needed and resources resulting from ongoing operations, and associated risks and uncertainties. ach financial statement entity must report on the efforts made and the results achieved in carrying out activities in a systematic and structured manner during a reporting period for accountability, managerial, transparency, and intergenerational equity.

First, accountability, responsible management of resources and the implementation of policies entrusted to the command entity in achieving the objectives that have been set periodically. Second, managerial, helps users to evaluate the implementation of the activities of a government entity in the reporting period, thus facilitating the planning, management and control functions of all assets, liabilities and government entities for the benefit of the community. Third, transparency, providing open and honest financial information to the community based on the consideration that the public has the right to know openly and comprehensively the responsibility of the government in managing the resources used to it and its compliance with laws and regulations. Finally, intergenerational equity, can be seen in capital expenditure transactions originating from loan funds. To improve the objective and disciplined abilities of the local $\mathrm{g}$ overnment in carrying out loan repayments, careful and prudent care is needed, in the management of this loan which aims to further regulate matters relating to local government loans by anticipating future needs and taking into account the need to maintain conditions strength and sustainability of the national economy.

\section{Method}

This type of research is qualitative. This research was conducted to analyze the application of regional financial accounting systems in the preparation of financial statements. The type of data in this paper is primary data, sourced from the 2013 and 2014 local financial statement documents, obtained from the Local Financial Management Agency of the Deli Serdang regency government - Indonesia, central and local government regulatory documents, and study literature. The data analysis technique used is a qualitative description technique.

\section{Results and Discussion}

\section{Geographical Description}

The Deli Serdang regency is located between $2^{\circ} 57$ - 316 North Latitude and $98^{\circ} 33$ $99^{\circ} 27$ East Longitude which is part of the region in a cross position in the western pacific trough region. With an area of 2,391.62 $\mathrm{km}^{2}(139,462 \mathrm{Ha})$. Administratively it consists of 24 sub-districts with 380 villages and 14 suburbs. Deli Serdang regency is bordered to the north by Langkat regency and the Malacca strait, south by Karo regency, west by Langkat regency and Karo regency, east by Serdang Bedagai regency.

This area is geographically located in the development area of the east coast of Sumatra and has a varied topography and climate, based on the topography, the Deli Serdang region is divided into three parts; 1 ) The coastal area is $\pm 63,002 \mathrm{Ha}(26.30 \%)$ consisting of 4 sub-districts (Hamparan Perak, Labuhan Deli, Percut Sei Tuan and Pantai Labu), the number of villages is 64 with a beach length of $\pm 62 \mathrm{~km}$. The main potentials are agriculture, food, small holder plantations, large estates, marine fisheries, mining, poultry farming, and tourism; 2) The land area is $\pm 68,965 \mathrm{Ha}$ (28.80\%) consisting of 11 districts (Sunggal, Pancur Baru, Namorambe, Deli Tua, Batang Kuis, Tanjung Morawa, Patumbak, 
Lubuk Pakam, Beringin, Pagar Merbau), the number of villages is 197; and 3) The highland area is $\pm 111,970 \mathrm{Ha}(44.90 \%)$ consisting of 7 subdistricts (Kutalimbaru, Sibolangit, SibiruBiru, STM Hilir, STM Hulu, Gunung Meriah, Bangun Purba). The number of villages is 133. The main potentials are smallholder agriculture, plantations, and livestock farming.

The total population at the end of 2014 was $\pm 1,463,031$ people and was the largest population in North Sumatra with a population growth rate of $2.09 \%$ and an average density of 598 people $/ \mathrm{km}^{2}$ while the composition of the population's livelihood was farmers $60.22 \%$, employees state or employees $21.83 \%$, traders $5.40 \%$, fishermen $2.86 \%$, services $3.17 \%$, craftsmen $0.40 \%$ and others $6.12 \%$ [11].

\section{Government Organizational Structure}

The government structure of Deli Serdang regency consists of; (1) government administrative assistants and municipal administration, consisting of (a) government and civil service sections, (b) village government sections, (c) legal and legislative sections; (2) the administrative assistant for development, consisting of (a) the administration of economic development, (b) the administration of facilities and infrastructure, (d) the administration of socio-cultural development; and (3) general administrative assistant, consisting of, (a) the apparatus empowerment section, (b) the financial section, (c) the equipment and maintenance section, (d) the general section.

\section{Government Financial Statements}

Government financial reports are reports on the responsibility of local governments for financial activities and economic resources that are enriched and show financial position by government financial accounting standards. The report is reflected in the local government financial statements consisting of 1) APBD statement; 2) APBD memorandum; 3) balance; and 4) cash flow statement.

The Deli Serdang regency government has compiled financial reports, which are referred to as the APBD reports of physical and financial realization per direct expenditure budget activities managed by the Deli Serdang regency government, in which the report preparation process is explained as follows;

1) The process of determining the basic budget plan, the activities carried out are:

a) The finance department, in charge of managing regional revenue sources together, estimates the target budget for revenue and development,

b) The department of determining the budget plan obtained by the Deli Serdang regency government is based on a circular from the Regent,

c) The development planning agency of the Deli Serdang regency government, the finance department, the part of the process of preparing the program together determine the development budget plan based on the priority scale of programs and projects in the five-year regional development plan.

2) The process of determining the development project, the activities carried out are;

a) repare and propose physical planning and details of project financing to be implemented,

b) conduct research on projects based on the scale of development priorities,

c) The finance department and the program preparation section will calculate the amount of research and the amount of research funding needed.

3) The process of determining the costs in the contract, the activities carried out are: 
a) The finance and program drafting division will conduct a tender, which is to make contracts and offer prices to the consultants.

b) The winner of the tender will be the company working on the contract for the project to be implemented.

c) The company before accepting payment transactions from the government is required to inspect the goods and get them recorded in the News of Inspection of Goods.

d) The finance and program preparation department will issue a News of Receipt of goods to the company after the company has made the payment transaction and received the payment receipt as proof of payment.

4) Expenditure determination process

a) The local government prepares and plans proposed activities, a list of project contents and an authorization decision letter, in which the authorization decision letter is submitted to the Regent of Deli Serdang,

b) then the Regent of Deli Serdang issued an authorization decision letter by the stipulated conditions,

c) The decree of the Regent of Deli Serdang was issued as an approval of the implementation of the development budget by the stipulated budget amount. Then the finance department issued a sum of money in the form of a check by a predetermined budget amount.

The financial accounting system implemented by the Deli Serdang regency government is the regional financial accounting system determined by Government Regulation 105 of 2000 [8]. This accounting system is different from the accounting system used before 2000, resulting in differences in the structure of financial statement formats. With the development of technology, the accounting system was developed computerized. The local government has made this happen by equipping its offices with a set of computers (hardware and software) that they need.

However, although local governments have used a computerized system in preparing financial statements, they are still experiencing delays. This is caused by human resource factors that cannot use the application system optimally and also an inadequate number of computers. Therefore, to further optimize the application of local financial accounting systems in the preparation of financial statements, local governments should provide training in the use of local financial accounting systems. Likewise with the educational background of employees who work in finance must have an economic-accountingcomputer knowledge base.

With the existence of a regional local accounting system that can meet the demands of financial accountability which is one of the principles of good governance so that public trust, the legislature, the business world, the public, and investors will be created. Increasing trust and providing reliable information to stakeholders will be very useful in efforts to improve local government performance.

The main obstacle is the unintegrated development of a financial management system that includes planning, budgeting, treasury, accounting, information systems, and auditing sub-systems. The guidelines issued are still partial and often do not match, so there must be an adjustment or conversion from one subsystem to another. Another obstacle is human resources, considering that the development of government accounting in Indonesia is not as fast as the development of commercial accounting, so far there are 
still few human resources who understand government accounting. Likewise with the lack of concern in the local government environment to base decisions on financial information.

Financial management procedures performed by the regency government consist of cash receipt procedures, cash disbursement procedures, and financial reporting. The procedure for cash receipts consists of regional tax receipts, local retribution directly to the local government treasury, all monetary value benefits in the form of commissions, rebates, interest deductions or other as a result of the sale or procurement of goods and the placement of local regional money is local income, and local income is paid fully on time to the local treasury in accordance with what was done by the local government.

The cash disbursement procedure consists of all expenses supported by complete evidence, the use of regional budgets that use pay orders to make payments. Likewise with employees who give authority to certify the evidence on which cash disbursements are based. This cash disbursement procedure is also by Government Regulation number 105 of 2000 [8] and Government Regulation number 108 of 2000 [12].

Reporting accountability at the end of the year consisting of APBD statements, APBD memorandum, cash flow statements, and balance sheets are appropriate. However, the accountability report format in the APBD statements is not appropriate because there is no comparison with the previous year, only limited to one period while in government regulation number 108 of 2000 there must be a comparison of one current period with the previous period. The financial reporting of the Deli Serdang regency government has used multiple accounting procedures although manually, as well as the cash flow statements that have listed the balance of the beginning of the previous year by Government Regulation number 105 of 2000 [8] and Government Regulation number 108 of 2000 [12]. The balance sheet on the Government of Deli Serdang regency has been used the $L$ Account.

\section{Conclusion}

While preparing the financial statements, the Deli Serdang regency government has used a local financial accounting system with inadequate equipment, which is a computerized system that is not yet understood and internet network infrastructure is still lacking so that the preparation of financial statements has been delayed. Another cause of delay in the preparation of financial statements, one of which is human resources. Skilled and cognitive human resources using the application of local financial accounting systems in local governments have not been sufficient, so the preparation of financial reports that have used regional financial accounting systems has been delayed. The organizational structure of the local government's financial management is in the form of a direct line, in which the leader has several subordinates and direct responsibility regarding his duties. This can facilitate coordination between leaders and employees and facilitate supervision.

\section{References}

1 Law of the Republic of Indonesia number 32 of 2004 concerning local government.

2 Law of the Republic of Indonesia number 22 of 1999 concerning local government.

3 Law of the Republic of Indonesia number 33 of 2004 concerning fiscal balance between the central and local government.

4 Law of the Republic of Indonesia number 25 of 1999 concerning central and local fiscal balance.

5 Minister of Home Affairs Regulation of the Republic of Indonesia number 29 of 2002 concerning Guidelines for the Preparation of Regional Financial Accountability and Procedures for Supervision of the Compilation and Calculation of the State Budget. 
106 Implementation of government financial information systems toward local government financial statements...

6 Government Regulation of the Republic of Indonesia number 8 of 2006 concerning Regional Financial.

7 Panggabean, F.Y \& Dame, I. Pengaruh Penerapan Sistem Keuangan Daerah, Transparansi Publik dan Aktivitas Pengendalian Terhadap Akuntanbilitas Keuangan di Kantor Kecamatan Kota Medan. Jurnal Akuntansi Bisnis dan Publik, 2018, 9 (1), pp.80-96. http://jurnal.pancabudi.ac.id/index.php/akuntansibisnisdanpublik/article/view/367

8 Government Regulation of the Republic of Indonesia number 105 of 2000 concerning Management and Accountability of Regional Finances.

9 Government Regulation of the Republic of Indonesia number 71 of 2010 concerning Government Accounting Standards.

10 Kasmir. Analisis Laporan Keuangan. Jakarta : Raja Grafindo Persada Press, 210.

11 Central Statistics Agency. 2015. Deli Serdang in Figures of 2015. https://deliserdangkab.bps.go.id/publication/download.html?nrbvfeve=NmZiZWE2NzQOMjRiMjZkNDVkOTZ mZDEz\&xzmn=aHROcHM6Ly9kZWxpc2VyZGFuZ2thYi5icHMuZ28uaWQvcHVibGljYXRpb24vMjAxNS8xMi8w OC82ZmJIYTY3NDQyNGlyNmQ0NWQ5NmZkMTMva2FidXBhdGVuLWRLbGktc2VyZGFuZy1kYWxhbS1hbmdrY SOyMDE1LmhObWw\%3D\&twoadfnoarfeauf=MjAyMSOwMiOwMSAyMDo0MDoyMw\%3D\%3D

12 Government Regulation of the Republic of Indonesia number 108 of 2000 concerning Procedures for the Accountability of Regional Heads and Procedures for the Preparation and Regulation of Regional Budget. 